\title{
Patient reported outcomes: past, present, and future
}

\author{
Jane A Scott \\ From Clinical Trials Methodology Conference 2011 \\ Bristol, UK. 4-5 October 2011
}

For decades, clinical trials have relied on information from patients about their symptoms, functioning, and treatment experiences to evaluate treatment safety and efficacy. Today, information reported directly by patients (patient reported outcomes or "PROs") using various technologies serves as the primary source of data about symptoms, functioning, health events, and the impact diseases and treatments have on the lives of patients and their families. The methods used to record and process that information has evolved over time so that today regulators require that trials use rigorous methods for all subjective assessments employed to evaluate treatments. This presentation is a brief review of the past, current, and future direction of PRO research and its implication for clinical trial measurement from the perspective of a PRO researcher working in medical product development trials.

Published: 13 December 2011

doi:10.1186/1745-6215-12-S1-A63

Cite this article as: Scott: Patient reported outcomes: past, present, and future. Trials 2011 12(Suppl 1):A63.

Submit your next manuscript to BioMed Central and take full advantage of:

- Convenient online submission

- Thorough peer review

- No space constraints or color figure charges

- Immediate publication on acceptance

- Inclusion in PubMed, CAS, Scopus and Google Scholar

- Research which is freely available for redistribution 